\title{
Expression of MMP9, SERPINE1 and miR-134 as prognostic factors in esophageal cancer
}

\author{
ANNA AGNIESZKA KLIMCZAK-BITNER ${ }^{1}$, RADZISŁAW KORDEK ${ }^{2,3}$, JAN BITNER ${ }^{4}$, \\ JACEK MUSIAŁ $^{5}$ and JANUSZ SZEMRAJ ${ }^{4}$
}

\begin{abstract}
${ }^{1}$ Department of Biomedical Chemistry, Faculty of Health Sciences with the Division of Nursing and Midwifery, Medical University of Lodz, Lodz 92-215; ${ }^{2}$ Department of Pathology, Faculty of Medicine, Medical University of Lodz, Lodz 93-509; ${ }^{3}$ Department of Surgical Oncology, Cancer Centre, Copernicus Memorial Hospital, Lodz 93-513; ${ }^{4}$ Department of Medicinal Biochemistry, Faculty of Health Sciences with the Division of Nursing and Midwifery, Medical University of Lodz, Lodz 92-215; ${ }^{5}$ Department of Histopathology, SYNEVO, Lodz 93-525; Poland
\end{abstract}

Received September 24, 2014; Accepted June 11, 2015

DOI: $10.3892 / \mathrm{ol} .2016 .5211$

\begin{abstract}
Esophageal cancer (EC) is a malignant tumor with a typically poor prognosis for patients. It is well known that certain microRNA (miRNA/miR) genes can regulate other genes responsible for carcinogenesis. In the present study, a group of these genes (miR-21, miR-134, miR-205 and miR-495) and genes connected with cancer-related pathways (MET, MMP9, PDGFA and SERPINE1) were chosen for analysis in order to find a potential correlation between their expression and the clinicopathological factors of EC. Esophageal tumors and adjacent non-cancerous tissue specimens were collected from a total of 63 patients and embedded in paraffin. Commercial arrays were used on KYSE-30, KYSE-150 and KYSE-270 EC cell lines in order to find genes of different expression profiles compared with those acquired from the control Het-1A cell line. Quantitative polymerase chain reaction was used on formalin-fixed, paraffin-embedded samples in order to analyze the expression of the genes chosen in the earlier step. The results were analyzed by the Kruskal-Wallis and Mann-Whitney U tests, Spearman's rank correlation coefficient, Kaplan-Meier methods and the long-rank test. Only miR-495 was not expressed in the analyzed samples. The expression of MMP9 and SERPINE1 was significantly coefficient with age range $(\mathrm{P}=0.011$ and $\mathrm{P}=0.044$, respectively) according to the Kruskal-Wallis test. The Spearman's rank-order correlation measurement showed that there was a coefficient correlation between age and miR-134 expression. The same measurement demonstrated a correlation between age range and MMP9 expression. The expression of miR-134
\end{abstract}

Correspondence to: Miss. Anna Agnieszka Klimczak-Bitner, Department of Biomedical Chemistry, Faculty of Health Sciences with the Division of Nursing and Midwifery, Medical University of Lodz, 6/8 Mazowiecka Street, Lodz 92-215, Poland

E-mail: a.a.klimczak@gmail.com

Key words: microRNA, esophageal cancer, genes, miR-134, MMP9, SERPINE1, miRNA databases and $M M P 9$ were also found to be correlated. In all cases, a value of $\mathrm{P}<0.049$ was recorded. Overall, the present study demonstrated that MMP9, SERPINE1 and miR-134 were the most prognostic genes in Caucasian patients with EC.

\section{Introduction}

Esophageal cancer (EC) has been well studied in the literature, being classified as sixth highest in terms of new cancer cases per year and the seventh leading cause of cancer-related mortality, worldwide (1-3). The incidence rate of EC is four-fold higher among males when compared with that among women $(1,2)$. A total of 450,000 new cases of EC are reported annually worldwide, among which 380,000 cases are expected to succumb to the disease within 12 months following diagnosis (1). In developed countries, EC accounts for $\sim 6 \%$ of malignant gastrointestinal cancer cases, with an extremely high mortality rate; $<10 \%$ of patients are expected to survive $>5$ years after diagnosis (1-3). There are two main types of EC, namely squamous cell carcinoma and adenocarcinoma. Certain genes, for example, oncogenes, tumor suppressor genes, metastasis genes and apoptosis genes, can have a giant impact on the development of EC (4). Risk factors including, alcohol consumption, smoking, chronic inflammation of the esophageal mucosa, achalasia, Plummer-Vinson syndrome, Barrett's esophagus and dietary factors (micronutrient and vitamin deficiencies, consumption of hot or highly processed products or food contaminated with spores or nitrogenous compounds) are considered increase the probability of EC development $(1,3)$. Notably, EC exhibits a significantly higher occurrence among smokers when compared with non-smokers. Both tobacco and alcohol consumption increase the risk of EC (1). Nowadays, a variety of methods exist to examine EC and more is known about the disease, however, further research is necessary in order to take effective steps to prevent and treat it (5). EC treatment choice is dependent on the developmental stage of the disease. For example, in cases of early cancer diagnosis, esophagectomy is possible (6). However, at later developmental stages, surgical anastomosis is performed using Kirschne-Akiyama gastric tube or fundus 
rotation gastroplasty techniques (7). In cases of unresectable EC, patients are treated with a combination of chemo- and radiotherapy (8). Laser therapy may also be used as an effective method for improving the patient's ability to swallow (9).

microRNAs (miRNAs/miRs) are non-coding small RNA molecules, well-conserved across diverse groups, for example, animals, plants and viruses (10). miRNAs can regulate the translation of mRNA and integrate different regulatory pathways for abnormal and normal cell development (11). It has been demonstrated that certain miRNAs have promising therapeutic potential (12). A number of miRNAs have been found to exhibit potential as prognostic factors in various cancer types, including miR155 and let-7a-2 (lung adenocarcinoma), miR21, miR-9-3 and miR145 (breast carcinoma) and miR18 and miR20 (hepatocellular carcinoma) (13-15).

For the present study, four genes connected with cancer-related pathways (PDGFA, MET, MMP9 and SERPINE1), as well as four miRNA genes (miR-21, miR-134, miR-205 and miR-495) were chosen. Angiogenesis describes the formation of new, thin-walled blood vessels from pre-existing vasculature. It is involved in numerous physiological and pathological processes, including chronic inflammation, ischemic diseases and solid tumor formation (16). Metastatic cascades are initiated by the invasion of tissues surrounding the tumor, followed by tumor cell infiltration of the surrounding blood vessels. Tumor cells are then transported further into the organism leading to the formation of metastatic colonies (17). These processes are prevalent in EC and are considered to be the primary cause of mortality (18). PDGFA, MET, MMP9 and SERPINE1 have been identified as the most promising genes involved in those processes based on miRNA gene expression analysis and literature data (19). PDGFA is involved in angiogenesis, while MET, MMP9 and SERPINE1 are involved in the invasion and metastasis of cancer $(20,21)$.

\section{Materials and methods}

EC cell lines and culture conditions. For the experiments, four different cell lines were used: Three EC lines (KYSE-30, KYSE-150 and KYSE-270), along with a Het-1A immortalized human esophageal epithelial cell line as a negative control. The three EC lines were obtained from the European Collection of Cell Cultures (Salisbury, UK), and the control cell line was ordered from the American Type Culture Collection (Manassas, VA, USA). The cancer cell lines were grown in a medium which consisted of Ham F12 and RPMI 1640 in a 1:1 ratio, with $2 \mathrm{mM}$ L-glutamine and $2 \%$ fetal bovine serum (Sigma-Aldrich, St. Louis, MO, USA). Quantum 286 medium (Sigma-Aldrich) was used to grow the Het-1A cell line. Standard conditions of $37^{\circ} \mathrm{C}, 5 \%(\mathrm{v} / \mathrm{v}) \mathrm{CO}_{2}$ and a relative humidity of $100 \%$ were used for the cultures, without antibiotics.

Contamination-free conditions in the cell culture room. Each experiment with cell lines was performed by a researcher with a number of years of experience with this type of work in a range of high-quality laboratories. In these institutions, antibiotics are not recommended for use in the cell culture room. A high-standard culture cell room was used for these experiments. Microscopic observations were performed every working day (Monday to Saturday) for the control of cell conditions. All liquids (i.e., media and buffers) and plastic equipment were sterile.

RNA isolation from cell lines. Small RNAs from the cell lines were recovered using the mirVana ${ }^{\mathrm{TM}}$ miRNA Isolation kit (Life Technologies, Carlsbad, CA, USA) according to the manufacturer's instructions. The quality and concentration of RNA was analyzed by the Picodrop Microliter UV/Vis Spectrophotometer (Picodrop Ltd., Hinxton, UK). RNA was used for the reverse transcription (RT) process directly after isolation.

miRNA genes analysis in cell lines. RT reactions for miRNA were performed with Megaplex ${ }^{\mathrm{TM}}$ Pools for microRNA Expression Analysis (Life Technologies). RT-qPCR was performed according to the manufacturer's instructions. The concentration of RNA used for conversion to cDNA was $700 \mathrm{ng} / \mu \mathrm{l}$, and the total volume of the RT polymerase chain reaction (PCR) reagents was $4.5 \mu \mathrm{l}$. The reactions were performed under the following conditions: 40 cycles of three steps: $16^{\circ} \mathrm{C}$ for $120 \mathrm{sec}$, $42^{\circ} \mathrm{C}$ for $60 \mathrm{sec}$ and $50^{\circ} \mathrm{C}$ for $1 \mathrm{sec}$. Following completion of the cycles, a final step was performed at $85^{\circ} \mathrm{C}$ for $5 \mathrm{~min}$. TaqMan ${ }^{\circledR}$ Array Human MicroRNA A (Life Technologies) was used to analyze 377 human microRNAs in the sample according to the manufacturer's instructions (22). Following analysis of the results and the associated literature, four miRNA genes were picked: miR-21, miR-134, miR-205 and miR-495. Significant differences in miR-134, miR-205 and miR-495 gene expression between cancer cell lines and controls have been identified previously (2), and miR21 expression has often been analyzed in the literature (23).

Analysis of cancer pathway genes in cell lines: Quantitative PCR (RT-qPCR). The RT ${ }^{2}$ Profiler $^{\mathrm{TM}}$ PCR Array (Qiagen, Venlo, Netherlands) was used to perform RT reactions for the genes correlated with the cancer-related pathways. A total of 84 genes representative of six biological pathways associated with transformation and tumorigenesis were checked with the Cancer PathwayFinder PCR Array (Qiagen) to choose four genes. The reactions were performed according to the manufacturer's instructions (19). The concentration of RNA used for conversion to cDNA was $1 \mu \mathrm{g} / \mu \mathrm{l}$, and the total volume of the RT PCR reagents was $20 \mu \mathrm{l}$. The reactions were performed under the following conditions: $25^{\circ} \mathrm{C}$ for $5 \mathrm{~min}, 42^{\circ} \mathrm{C}$ for $5 \mathrm{~min}$, $55^{\circ} \mathrm{C}$ for $15 \mathrm{~min}$ and $95^{\circ} \mathrm{C}$ for $5 \mathrm{~min}$. Following completion of the cycles, a final step was performed at $85^{\circ} \mathrm{C}$ for $5 \mathrm{~min}$. After analysis of the results and knowledge from literature, four miRNA genes were picked: $M E T, M M P 9, P D G F A$ and SERPINE1.

Tissue samples from patients. Esophageal tumors and adjacent non-cancerous specimens were collected from a total of 126 cancerous and non-cancerous samples from 63 patients undergoing surgical resection, primarily for diagnosis. Non-cancerous samples were taken from tumor-free tissue at least $5 \mathrm{~cm}$ from the tumor-like lesions. Samples were collected between 2005 and 2013 at the M. Kopernik Provincial Specialist Hospital in Lodz (Lodz, Poland). Each diagnosis was confirmed through microscopic examination by licensed pathologists and written informed consent for use of the tissues in research studies was provided by each patient. Tissues 
Table I. Clinical and pathological characteristics for patients (n=63) with EC and the association between MMP9 and SERPINE1 expression and patient clinicopathological factors.

\begin{tabular}{|c|c|c|}
\hline Characteristics & Patients, n (\%) & $\begin{array}{c}\text { P-value } \\
\text { (MMP9; } \\
\text { SERPINE1) }\end{array}$ \\
\hline Gender & & $\mathrm{P}=0.505 ; \mathrm{P}=0.817$ \\
\hline Female & $16(25.4)$ & \\
\hline Male & $47(74.6)$ & \\
\hline Age, years ${ }^{\mathrm{a}}$ & & $\mathrm{P}=0.011^{\mathrm{b}} ; \mathrm{P}=0.044^{\mathrm{b}}$ \\
\hline$<45$ & $5(7.9)$ & \\
\hline $45-55$ & $12(19.0)$ & \\
\hline $56-65$ & $34(54.0)$ & \\
\hline$>65$ & $12(19.0)$ & \\
\hline Type of EC & & $\mathrm{P}=0.241 ; \mathrm{P}=0.235$ \\
\hline $\mathrm{SCC}$ & $38(60.3)$ & \\
\hline $\mathrm{AC}$ & $22(34.9)$ & \\
\hline $\mathrm{BSCC}$ & $1(1.6)$ & \\
\hline CS & $1(1.6)$ & \\
\hline ASC & 1 (1.6) & \\
\hline AJCC system & & $\mathrm{P}=0.504 ; \mathrm{P}=0.543$ \\
\hline $\mathrm{I}+\mathrm{II}$ & $22(34.9)$ & \\
\hline III+IV & $28(44.4)$ & \\
\hline No data & $13(20.6)$ & \\
\hline Lymph node metastasis & & $\mathrm{P}=0.309 ; \mathrm{P}=0.934$ \\
\hline Negative & $33(52.4)$ & \\
\hline Positive & $17(27.0)$ & \\
\hline No data & $13(20.6)$ & \\
\hline Family history of cancer & & $\mathrm{P}=0.465 ; \mathrm{P}=0.639$ \\
\hline Yes & $5(7.9)$ & \\
\hline No & $48(92.1)$ & \\
\hline Other cancers & & $\mathrm{P}=0.534 ; \mathrm{P}=0.526$ \\
\hline Yes & $15(23.8)$ & \\
\hline No & $48(76.2)$ & \\
\hline Alcohol consumption & & $\mathrm{P}=0.743 ; \mathrm{P}=0.366$ \\
\hline Rarely & $39(61.9)$ & \\
\hline Often & $24(38.1)$ & \\
\hline Smoking status & & $\mathrm{P}=0.826 ; \mathrm{P}=0.008^{\mathrm{b}}$ \\
\hline Never & $14(22.2)$ & \\
\hline Ever & $49(77.8)$ & \\
\hline Packs of cigarettes/day & & $\mathrm{P}=0.057 ; \mathrm{P}=0.942$ \\
\hline 0 & $14(22.2)$ & \\
\hline$\leq 2$ & $34(54.0)$ & \\
\hline$>2$ & $15(23.8)$ & \\
\hline Years of smoking & & $\mathrm{P}=0.081 ; \mathrm{P}=0.032^{\mathrm{b}}$ \\
\hline$<20$ & $11(23.4)$ & \\
\hline $21-30$ & $15(31.9)$ & \\
\hline$>31$ & $21(44.7)$ & \\
\hline
\end{tabular}

aRange, 28-74 years. $\quad{ }^{\mathrm{b}} \mathrm{P}<0.05 . \quad \mathrm{EC}, \quad$ esophageal cancer; AJCC, American Joint Committee on Cancer; SCC, squamous cell carcinoma; BSCC, basaloid SCC; ASC, adenosquamous carcinoma; CS, chondrosarcoma.
Table II. TaqMan ${ }^{\circledR}$ MicroRNA Assay primers used to amplify miRNA genes in quantitative polymerase chain reaction.

\begin{tabular}{lc}
\hline Gene & Assay ID \\
\hline RNU24 & 001001 \\
miR-21 & 002438 \\
miR-134 & 001186 \\
miR-205 & 000509 \\
miR-495 & 001663 \\
\hline
\end{tabular}

miR/miRNA, microRNA.

were put through a paraffin cell block preparation procedure. Samples were kept at $4^{\circ} \mathrm{C}$ in dry storage conditions. The Bioethics Committee for Research on Humans at the Medical University of Lodz (Lodz, Poland) approved this project as one following the Declaration of Helsinki. All patient information, including gender, age, alcohol consumption, smoking status, history of cancer, other cancers and histopathology is recorded in Table I. All patients belonged to the Caucasian population.

RNA isolation from formalin-fixed,paraffin-embedded(FFPE) samples. Total RNA of the EC and non-cancerous specimens was extracted from FFPE tissues using the High Pure FFPE RNA Micro kit (Roche, Basel, Switzerland) according to the manufacturer's instructions. The quality and concentration of RNA was analyzed by the Picodrop Microfilter UV/Vis Spectrophotometer (Picodrop Ltd.). Directly after isolation, RNA was used in the reverse transcription process.

FFPE sample miRNA gene analysis: RT-qPCR. The TaqMan Reverse Transcription kit (Life Technologies) was used according to the manufacturer's instructions in a UNO-Thermoblock from Biometra (Goettingen, Germany). Commercial primers were used in each reaction with TaqMan Universal Master Mix II without UNG (Life Technologies) according to the manufacturer's instructions. RNU24 was used as a control (Table II). Three samples were amplified simultaneously. The 7900HT Fast Real Time OCR System (Life Technologies) was used.

FFPE sample analysis for genes correlated with cancer pathways: RT-qPCR. PCR primers (Table III) were used with the addition of Brilliant II SYBR ${ }^{\circledR}$ Master Mix (Agilent Technologies Inc., Santa Clara, CA, USA). GAPDH was used as an endogenous control. For MET, SERPINE1 and PDGFA, the reactions were performed under the following conditions: $95^{\circ} \mathrm{C}$ for $10 \mathrm{~min}$, followed by 40 cycles of $95^{\circ} \mathrm{C}$ for $30 \mathrm{sec}$ and $60^{\circ} \mathrm{C}$ for $25 \mathrm{sec}$. For $M M P 9$, the reactions were performed using the following conditions: $95^{\circ} \mathrm{C}$ for $10 \mathrm{~min}$, followed by 40 cycles of $95^{\circ} \mathrm{C}$ for $30 \mathrm{sec}$ and $63^{\circ} \mathrm{C}$ for $30 \mathrm{sec}$. Three reactions were performed simultaneously. Nuclease-free water was used as a control for each experiment to ensure that there was no contamination. qPCR was performed on the Agilent Technology Mx3005P instrument (Agilent Technologies Inc.).

Statistical analysis. The Wilcoxon rank-sum test was used to appraise the correlation between genes in the EC tumors 
Table III. PCR primers used to amplify genes correlated with cancer pathways in qPCR reaction.

\begin{tabular}{|c|c|c|c|}
\hline Genes & Primers sequence $\left(5^{\prime}-3^{\prime}\right)$ & Product size, bp & Annealing temperature, ${ }^{\circ} \mathrm{C}$ \\
\hline$G A P D H$ & $\begin{array}{l}\text { F: AGCCACATCGCTCAGACA } \\
\text { R: GCCCAATACGACCAAATCC }\end{array}$ & 66 & $\begin{array}{l}60.0 \\
63.0\end{array}$ \\
\hline$M E T$ & $\begin{array}{l}\text { F: TTCTGACCGAGGGAATCAT } \\
\text { R: CCTTCACTTCGCAGGCAG }\end{array}$ & 82 & 60.0 \\
\hline$M M P 9$ & $\begin{array}{l}\text { F: GAACCAATCTCACCGACAGG } \\
\text { R: GCCACCCGAGTGTAACCATA }\end{array}$ & 67 & 63.0 \\
\hline PDGFA & $\begin{array}{l}\text { F: CCCCTGCCCATTCGGAGGAAGAG } \\
\text { R: TTGGCCACCTTGACGCTGCGGTG }\end{array}$ & 227 & 60.0 \\
\hline SERPINE1 & $\begin{array}{l}\text { F: CTCTCTCTGCСCTCACCAA } \\
\text { R: GAAACTGTCTGAACATGTCG }\end{array}$ & 183 & 60.0 \\
\hline
\end{tabular}

F-forward; R-reverse; qPCR, quantitative polymerase chain reaction.

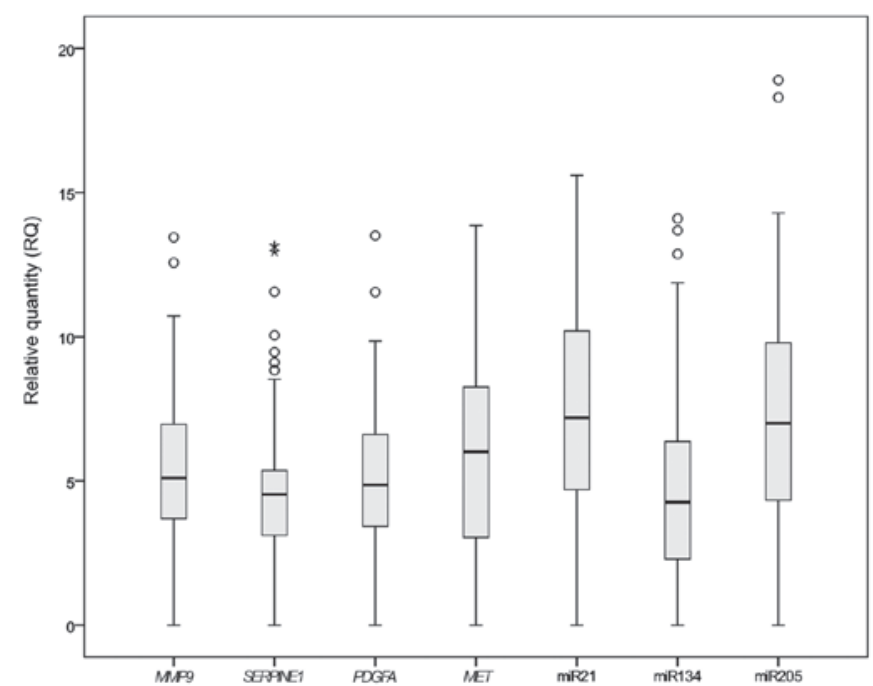

Figure 1. Gene expression in esophageal cancer samples. Boxplot showing the relative expression of genes. Ct values from quantitative polymerase chain reaction were normalized against RNU24, and the relative expression was calculated by the $2^{-\Delta \Delta C t}$ method. Outliers are represented by circles and extreme outliers are represented by stars. The P-values for $M M P 9$, SERPINE1, PDGFA, MET, miR-21, miR-134 and miR-205 were $\mathrm{P}=0.046$, $\mathrm{P}=0.001, \mathrm{P}=0.041, \mathrm{P}=0.019, \mathrm{P}=0.045, \mathrm{P}=0.002$ and $\mathrm{P}=0.009$, respectively, as determined by the Mann-Witney $\mathrm{U}$ test. miR, microRNA.

and adjacent non-cancerous specimens. Correlations between genes and clinicopathological factors were tested using the Kruskal-Wallis and Mann-Whitney U tests. Spearman's correlation coefficient was also calculated. $\mathrm{P}<0.05$ was used to indicate a statistically significant difference. Survival was estimated using Kaplan-Meier methods and the long-rank test. Calculations were prepared by STATISTICA version 10 (StatSoft, Inc., Tulsa, OK, USA) and IBM SPSS version 19 (IBM, Armonk, NY, USA).

\section{Results}

Expression of genes. Expression levels of miR-21, miR-134 and miR-205 were significantly higher in all the EC samples than in the non-cancerous controls. Only miR-495 was not
A

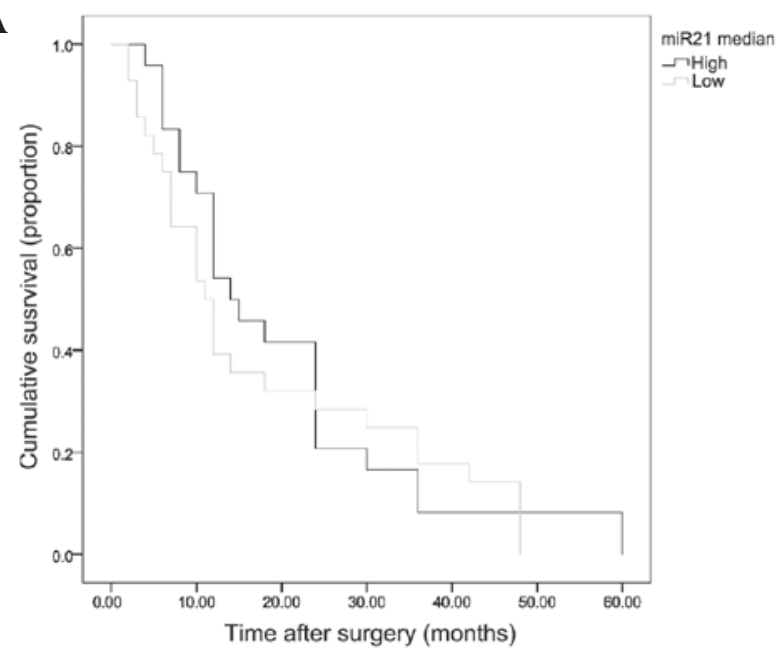

B

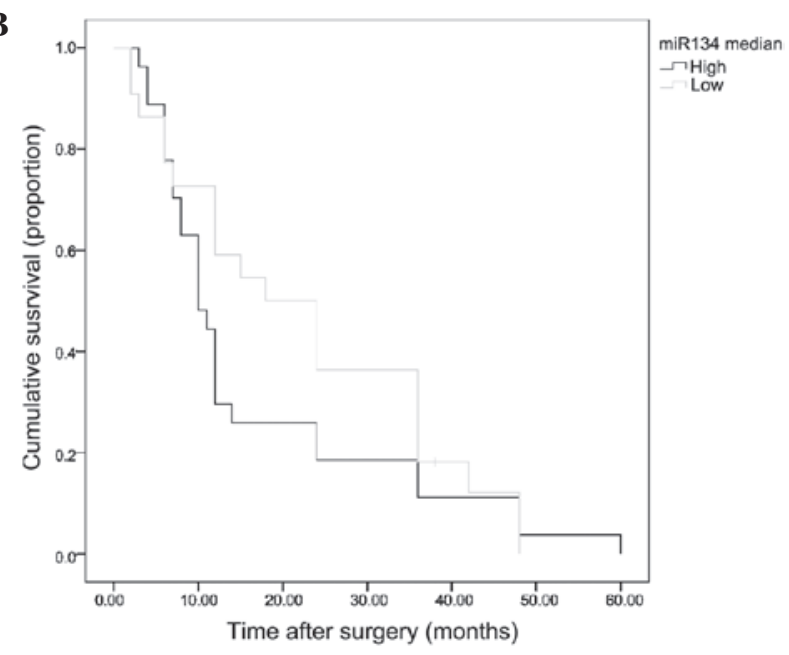

Figure 2. Kaplan-Meier analysis for selected genes. The 56 patients were divided into two groups based on gene expression, with a higher or lower than the median value ( $\mathrm{n}=28$ for each). (A) $\mathrm{P}=0.278$ and (B) $\mathrm{P}=0.183$. miR, microRNA.

expressed in the FFPE samples. All the cancer pathway-associated genes that has been selected for the study on FFPE (MET,MMP9, PDGFA and SERPINE1) exhibited significantly 
higher expression levels in the $63 \mathrm{EC}$ samples than in the adjacent non-cancerous specimens $(\mathrm{P}<0.05)$ (Fig. 1).

Association between genes and clinicopathological factors. One significant correlation was found between the miRNA genes and clinicopathological factors: Age was positively correlated with miR-134 expression $(\mathrm{P}<0.039)$, as determined by Spearman's rank correlation coefficient. The expression of two of the cancer pathway-associated genes, MMP9 and SERPINE1, was significantly correlated with the clinicopathological factors. MMP 9 was positively correlated with age $(\mathrm{P}<0.002)$, while SERPINE1 was positively correlated with smoking status $(\mathrm{P}<0.0015)$ and with the number of years of smoking $(\mathrm{P}<0.029)$. All these results were acquired by calculating Spearman's rank correlation coefficient. The Kruskal-Wallis test and the Mann-Whitney U test confirmed this data. MMP9 and SERPINE1 exhibited a significant correlation with age $(\mathrm{P}=0.011$ and $\mathrm{P}=0.044$, respectively). In addition, SERPINE1 was significantly correlated with smoking and the number of years of smoking $(\mathrm{P}=0.008$ and $\mathrm{P}=0.032$, respectively).

Correlation between genes. One positive correlation between an miRNA gene and the expression of a cancer pathway-associated gene was proven for miR-134 and $M M P 9$, with statistical significance $(\mathrm{P}<0.019)$, as determined using Spearman's rank correlation coefficient.

Survival analysis. The available survival data for 56 of the 63 patients $(88.9 \%)$ analyzed against miR-21 and miR-134 expression is shown (Fig. 2). Survival plots for miR-21 and miR-134 showed differences between high and low expression, but these differences were not significant $(\mathrm{P}=0.278$ and $\mathrm{P}=0.183$, respectively). Gender, American Joint Committee on Cancer system classification and type of EC were identified as invariable upon analysis (data not shown).

\section{Discussion}

In the present study of EC, the expression of seven genes was detected (miR-495 was not expressed in the FFPE samples). For each of the genes, MET, MMP9, PDGFA, SERPINE1, miR-21, miR-134 and miR-205, the results were significant in comparison to adjacent non-cancerous specimens. The study investigated whether the expression of these genes in EC was correlated with clinicopathological factors and prognosis of EC patients. For MMP9, SERPINE1 and miR-134, the results were significant, as determined by the Kruskal-Wallis and Mann-Whitney U tests, and Spearman's correlation coefficient. It is noteworthy that for the first time in the literature a correlation was detected between MMP9 and miR-134.

Different miRNA databases were used to analyze the genes for the present study: miR2Disease (http://www.mir2disease. org/), miRecords (http://c1.accurascience.com/miRecords/), miRSel (https://services.bio.ifi.lmu.de/mirsel/), miRTarBase (http://mirtarbase.mbc.nctu.edu.tw/) and miRWalk (http://www.umm.uni-heidelberg.de/apps/zmf/mirwalk/), starBase v2.0 (http://starbase.sysu.edu.cn/) and DIANA Lab's TarBase (http://diana.imis.athena-innovation.gr/DianaTools/index.php? $r=$ tarbase/index). In miR2Disease only
EC-related data could be found on miR-21 and miR-205 (24). There were records for miR-134 and miR-495, but with regard to other diseases.

Only miR-21 and miR-205 were described in the miRecords target miRNA search, but no information with regard to the correlation of the genes and the EC pathways was mentioned. MET was included in the target gene search results, but was not associated with the miRNA genes of the present study. However, in miRSel there was information on a correlation between miR-21 and MMP9. miR-134 was correlated with $P D G F R A$, a receptor for $P D G F A$, which was analyzed in the present study. None of the 98 available records for miR-205 were connected with genes correlated with cancer pathways. There was no record for miR-495. For the miRTarBase, only one correlation between miR-21 and MMP9 was found (25).

A notable correlation was shown by the miRWalk database, according to which PDGFA is situated on the miR-495 stem-loop. SEPRINE1 is located on the stem-loop of miR-134 in the UTR. In starBase v2.0 no records were found. In DIANA Lab's TarBase, only a correlation between miR-21 and $M M P 9$ was found. The aforementioned analyses are current as of September 2014, and the list of miRNA databases is based on those used by Vergoulis et al (26).

Houldsworth et al (27) identified an association between MET and EC, while Gu et al (28) showed that MMP9 affected the survival of patients with this disease. PDGFA was detected in EC by Wong et al (29) and Aoki et al (30) suggested that SERPINE1 may be a potentially important index for the prediction of post-operative illness.

A correlation between miR-134 and the duration of survival with this disease has also been found (31). Guo et al demonstrated a correlation between miR-495 and the gross pathological classification of EC (32). There is no information with regard to miR-134 and the genes analyzed for this study in EC or even for other cancers in the case of $M M P 9$. There are no studies in the literature of miR-205 and miR-495 and genes from this study regarding EC.

As MMP9 and SERPINE1 have shown correlation with clinicopathological factors, information on their proteins was obtained. Search Tool for the Retrieval of Interacting Genes/Proteins has been used to study the interactions between genes and their protein products (33). It was found that SERPINE1 and MMP9 are separated in interactions by PLAU. It is known that there is a strong correlation between SERPINE1 and MMP9 in pancreatic cancer (34). There is only one abstract with regard to this interaction in EC (35). Kajiwara et al measured the expression of these two genes in EC, but did not find a significant interaction between them (20).

In conclusion, the present study identified genes with expression that was correlated with the clinicopathological factors of EC. MMP9, SERPINE1 and miR-134 are the most prognostic genes analyzed in this population-based study of EC. Moreover, a positive correlation was established between MMP9 and miR-134, which has not previously been reported with regards to esophageal cancer.

\section{Acknowledgements}

This study was supported by a research project grant from the Medical University of Lodz (no. 502-64-002). 


\section{References}

1. Boyle P and Levin B (eds): World Cancer Report 2008. IARC, Lyon, France, 2008.

2. Jemal A, Bray F, Center MM, Ferlay J, Ward

3. Klimczak A, Bitner J and Szemraj J: Genes responsible for etiopathogenesis in esophageal squamous cell carcinoma. Postepy Biochem 57: 33-40, 2011 (In Polish).

4. Lam AK: Molecular biology of esophageal squamous cell carcinoma. Crit Rev Oncol Hematol 33: 71-90, 2000.

5. Klimczak A, Kuropatwa A, Lewkowski J and Szemraj J: Synthesis of new $\mathrm{N}$-arylamino (2-furyl) methylphosphonic acid diesters and in vitro evaluation of their cytotoxicity against esophageal cancer cells. Med Chem Res 22: 852-860, 2013.

6. Law S and Wong J: Therapeutic options for esophageal cancer. J Gastroenterol Hepatol 19: 4-12, 2004.

7. Hartwig W, Strobel O, Schneider L, Hackert T, Hesse C, Büchler MW and Werner J: Fundus rotation gastroplasty vs. Kirschner-Akiyama gastric tube in esophageal resection: Comparison of perioperative and long-term results. World J Surg 32: 1695-1702, 2008.

8. Ordu AD, Nieder C, Geinitz H, Kup PG, Deymann LF, Scherer V, Combs SE and Fakhrian K: Radio(chemo)therapy for locally advanced squamous cell carcinoma of the esophagus: Long-term outcome. Strahlenther Onkol 191: 153-160, 2015

9. Rabenstein T: Palliative endoscopic therapy of esophageal cancer. Viszeralmedizin 31: 354-359, 2015.

10. Carrington JC and Ambros V: Role of microRNAs in plant and animal development. Science 301: 336-338, 2003.

11. Kim VN, Han J and Siomi MC: Biogenesis of small RNAs in animals. Nat Rev Mol Cell Biol 10: 126-139, 2009.

12. Thorsen SB, Obad S, Jensen NF, Stenvang J and Kauppinen S: The therapeutic potential of microRNAs in cancer. Cancer J 18: 275-284, 2012.

13. Yanaihara N, Caplen N, Bowman E, Seike M, Kumamoto K, Yi M, Stephens RM, Okamoto A, Yokota J, Tanaka T, et al: Unique microRNA molecular profiles in lung cancer diagnosis and prognosis. Cancer cell 9: 189-198, 2006.

14. Iorio MV, Ferracin M, Liu CG, Veronese A, Spizzo R, Sabbioni S, Magri E, Pedriali M, Fabbri M, Campiglio M, et al: MicroRNA gene expression deregulation in human breast cancer. Cancer Res 65: 7065-7070, 2005.

15. Murakami Y, Yasuda T, Saigo K, Urashima T, Toyoda H, Okanoue $\mathrm{T}$ and Shimotohno K: Comprehensive analysis of microRNA expression patterns in hepatocellular carcinoma and non-tumorous tissues. Oncogene 25: 2537-2545, 2006.

16. Johnson KE and Wilgus TA: Vascular Endothelial Growth Factor and Angiogenesis in the Regulation of Cutaneous Wound Repair. Adv Wound Care (New Rochelle) 3: 647-661, 2014.

17. Valastyan S and Weinberg RA: Tumor metastasis: Molecular insights and evolving paradigms. Cell 47: 275-292, 2011.

18. Bal J: Biologia Molekularna W Medycynie. Wydawnictwo Naukowe PWN, Warszawa, 2011 (In Polish).

19. Qiagen: RT2 Profiler PCR Array Handbook. Qiagen, USA, pp27-48, 2011.

20. Kajiwara T, Hiasa Y, Nishina T, Matsumoto T, Hori S, Nadano S, Iguchi $\mathrm{H}$, Takeji $\mathrm{S}$, Tsubouchi E, Ikeda Y, et al: Maximum standardized uptake value in 18F-fluoro-2-deoxyglucose positron emission tomography is associated with advanced tumor factors in esophageal cancer. Mol Clin Oncol 2: 313-321, 2014.
21. Kameyama H, Udagawa O, Hoshi T, Toukairin Y, Arai T and Nogami M: The mRNA expressions and immunohistochemistry of factors involved in angiogenesis and lymphangiogenesis in the early stage of rat skin incision wounds. Leg Med (Tokyo) 17: 255-260, 2015.

22. Biosystems A: Megaplex ${ }^{\mathrm{TM}}$ Pools For microRNA Expression Analysis. Biosystems A, USA, pp15-22, 2010.

23. Akagi I, Miyashita M, Ishibashi O, Mishima T, Kikuchi K, Makino H, Nomura T, Hagiwara N, Uchida E and Takizawa T: Relationship between altered expression levels of MIR21, MIR143, MIR145, and MIR205 and clinicopathologic features of esophageal squamous cell carcinoma. Dis Esophagus 24: 523-530, 2011.

24. Feber A, Xi L, Luketich JD, Pennathur A, Landreneau RJ, Wu M, Swanson SJ, Godfrey TE and Litle VR: MicroRNA expression profiles of esophageal cancer. J Thorac Cardiovasc Surg 135: 255-260; discussion 260, 2008.

25. Giovannetti E, Funel N,Peters GJ,Del Chiaro M,Erozenci LA, Vasile E, Leon LG, Pollina LE, Groen A and Falcone A: MicroRNA-21 in pancreatic cancer: Correlation with clinical outcome and pharmacologic aspects underlying its role in the modulation of gemcitabine activity. Cancer Res 70: 4528-4538, 2010.

26. Vergoulis T, Vlachos IS, Alexiou P, Georgakilas G,Maragkakis M, Reczko M, Gerangelos S, Koziris N, Dalamagas T and Hatzigeorgiou AG: TarBase 6.0: Capturing the exponential growth of miRNA targets with experimental support. Nucleic Acids Res 40: D222-D229, 2012.

27. Houldsworth J, Cordon-Cardo C, Ladanyi M, Kelsen DP and Chaganti RS: Gene amplification in gastric and esophageal adenocarcinomas. Cancer Res 50: 6417-6422, 1990.

28. Gu ZD, Li JY, Li M, Gu J, Shi XT, Ke Y and Chen KN: Matrix metalloproteinases expression correlates with survival in patients with esophageal squamous cell carcinoma. Am J Gastroenterol 100: 1835-1843, 2005

29. Wong FH, Hu CP, Chen SC, Yu YT and Chang C: Absence of genomes of DNA tumor viruses and expression of oncogenes and growth factors in two esophageal carcinoma cell lines of Chinese origin. Zhonghua Min Guo Wei Sheng Wu Ji Mian Yi Xue Za Zhi 25: 59-68, 1992.

30. Aoki K, Nishino N, Baba S, Urano T and Takada A: Postoperative changes in plasma tissue-type plasminogen activator and type 1 plasminogen activator inhibitor. Surg Today 24: 1039-1043, 1994

31. Hamano R, Miyata H, Yamasaki M, Kurokawa Y, Hara J, Moon JH, Nakajima K, Takiguchi S, Fujiwara Y, Mori M and Doki Y: Overexpression of miR-200c induces chemoresistance in esophageal cancers mediated through activation of the Akt signaling pathway. Clin Cancer Res 17: 3029-3038, 2011.

32. Guo Y, Chen Z, Zhang L, Zhou F, Shi S, Feng X, Li B, Meng X, Ma X, Luo M, et al: Distinctive microRNA profiles relating to patient survival in esophageal squamous cell carcinoma. Cancer Res 68: 26-33, 2008 .

33. Snel B, Lehmann G, Bork P and Huynen MA: STRING: A web-server to retrieve and display the repeatedly occurring neighbourhood of a gene. Nucleic Acids Res 28: 3442-3444, 2000.

34. Wagner M,Kleeff J, Friess H, Buchler MW and Korc M: Enhanced expression of the type II transforming growth factor-beta receptor is associated with decreased survival in human pancreatic cancer. Pancreas 19: 370-376, 1999.

35. Pidgeon GP, Allott E, Donohoe C, Cathcart M, McGarrigle S, Cummins R, Kay E and Reynolds J: Adipose tissue upregulates MMP9 expression in oesophageal cancer promoting invasion and migration in vitro and correlates with obesity status and poor differentiation in vivo. Cancer Res 71 (Suppl): abstract 1556, 2011. 